\title{
Spatial and Temporal Increase of Eastern Filbert Blight in European Hazelnut Orchards in the Pacific Northwest
}

\author{
J. N. Pinkerton, K. B. Johnson, D. E. Aylor, and J. K. Stone
}

First author: U.S. Department of Agriculture-Agricultural Research Service, Horticultural Crops Research Laboratory, 3340 NW Orchard Ave., Corvallis, OR 97330; second and fourth authors: Department of Botany and Plant Pathology, Oregon State University, Corvallis 97330; and third author: Department of Plant Pathology and Ecology, The Connecticut Agricultural Experiment Station, P.O. Box 1106, New Haven 06504.

Accepted for publication 23 August 2001.

\begin{abstract}
Pinkerton, J. N., Johnson, K. B., Aylor, D. E., and Stone, J. K. 2001. Spatial and temporal increase of eastern filbert blight in European hazelnut orchards in the Pacific Northwest. Phytopathology 91:12141223 .

Since its first detection in southwest Washington state 30 years ago, eastern filbert blight, caused by Anisogramma anomala, has spread slowly southward $(\approx 2 \mathrm{~km} /$ year) into the Willamette Valley of Oregon, an important hazelnut production region. Experiments were conducted to measure gradients of disease spread, rates of disease increase as affected by distance from an inoculum source and variation in host plant resistance, and dispersal of ascospores of $A$. anomala from diseased orchards. In each of 3 years, 1-year-old hazelnut trees placed from 0 to $150 \mathrm{~m}$ north of diseased orchards were infected uniformly and slopes of disease gradients were not significantly different from zero. In 1 year when trees also were placed south of an orchard, the disease gradient was significant $(P<0.05)$, with disease incidence high at the edge of the orchard and few trees infected at $10 \mathrm{~m}$ south of the orchard. Disease gradients were

shallower and the magnitude of the area under the disease progress curve (AUDPC) greater in 0.1-ha mini-orchards of highly susceptible cv. Ennis than in mini-orchards of moderately susceptible cvs. Barcelona or Casina. Lower AUDPC values were observed in mini-orchards of Barcelona interplanted with a moderately resistant pollenizer Hall's Giant compared with the highly susceptible pollenizer Daviana. Fungicides applied biweekly starting at bud break reduced AUDPC values in Ennis miniorchards to values observed in Barcelona and Casina mini-orchards. Data from aspirated spore samplers placed on towers adjacent to severely diseased hazelnut orchards indicated that spores of $A$. anomala dispersed horizontally and vertically away from the canopy during periods of extended branch wetness and, thus, show potential to be transported long distances in wind currents. Weather patterns in the Pacific Northwest may account for the relatively slow, southward spread of eastern filbert blight within Oregon's Willamette Valley. Of 196 precipitation events greater than $10 \mathrm{~h}$ in duration recorded from 1974 to 1995 , conditions most favorable for ascospores discharge, periods with wind from the north were rare, representing $<6 \%$ of total hours.
\end{abstract}

Eastern filbert blight, caused by Anisogramma anomala (Peck) E. Müller in E. Müller \& Arx (Diaporthales), is a devastating canker and dieback disease of European hazelnut, Corylus avellana L. A. anomala was introduced into southwest Washington approximately 30 years ago, most likely on infected Corylus spp. shipped from eastern North America, where A. anomala is endemic on C. americana (5). In 1986, the disease was found at the northern end of the Willamette Valley of Oregon, where European hazelnut is produced commercially on 12,000 ha (21). Most hazelnut orchards located along the northern edge of the Willamette Valley and in southern Washington have been destroyed by the disease (21). In orchards planted with highly susceptible cultivars (e.g., Ennis), eastern filbert blight spreads rapidly and entire canopies typically die back in 4 to 5 years if not protected with fungicides. In plantings of moderately susceptible cultivars (e.g., Barcelona), trees become unproductive after 8 to 15 years $(12,18)$.

Ascospores of $A$. anomala infect immature hazelnut shoots in the spring $(13,22,25)$. Approximately 1 year after infection, a perennial canker develops at the site of infection $(8,13)$. Stromata begin to form in the cankers in May, asci develop in late summer, and ascospores mature during the fall $(8,20)$. Ascospores dis-

Corresponding author: J. N. Pinkerton; E-mail address: pinkertj@bcc.orst.edu

Publication no. P-2001-1017-01R

This article is in the public domain and not copyrightable. It may be freely reprinted with customary crediting of the source. The American Phytopathological Society, 2001. charged during the following spring complete the 2-year life cycle (8). For existing infections, cankers expand in subsequent years and new stromata are produced at the margins of the cankers.

Over the last 30 years, the epidemic of eastern filbert blight in western Oregon has progressed slowly to the south, with the majority of diseased orchards located less than $60 \mathrm{~km}$ from the original detection $(9,21)$. Gottwald and Cameron $(9,10)$ concluded that ascospores were splash dispersed based on the distribution of ascospores of $A$. anomala on glass slides placed above cankers, the absence of ascospores collected in a Burkhard volumetric trap, and the relatively slow rate of disease spread in and among orchards. In more recent surveys of Oregon hazelnut orchards (21), however, orchards with eastern filbert blight were found more than $10 \mathrm{~km}$ from the nearest neighboring diseased orchard, suggesting spore movement by mechanisms other than rain splash $(7,14,24)$. Pinkerton et al. (20) concluded from volumetric spore trap data that ascospores of $A$. anomala are actively discharged, showing potential to be transported long distances in parcels of air $(1,6,17,23)$. Ascospores of $A$. anomala remain viable for 3 to 7 days (13; J. N. Pinkerton, unpublished data), ample time to be transported by wind throughout the hazelnut production area. Based on observed patterns of disease spread in Oregon orchards, it has been suggested that spores are dispersed readily to the north with the prevailing winds that accompany major rain events, but rarely to the south (21).

More knowledge of the relationship between ascospore release and dispersal, regional weather patterns, and the spread and rate of increase of eastern filbert blight would provide a better understanding of the current epidemic and improve the estimation of the 
probability of disease spread into unaffected regions. Toward those ends, the objectives of this research were to investigate disease increase as affected by distance from an inoculum source and level of host plant resistance, and to define dispersal gradients of ascospores of A. anomala.

\section{MATERIALS AND METHODS}

Disease gradient experiment. In February 1989, 1-year-old hazelnut trees of highly susceptible cv. Royal were planted in an open field north of a 12-ha, 50-year-old European hazelnut orchard near Troutdale, OR. The orchard had not been managed for 4 years and the hazelnut trees within the orchard were severely diseased. One-year-old trees of cv. Royal were planted in six 90-m rows perpendicular to the north edge of the orchard. Both rows and trees within rows were spaced $5 \mathrm{~m}$ apart. Each Royal tree was 1 to $1.2 \mathrm{~m}$ tall and had $\approx 35$ buds. All volunteer hazelnut trees within $\approx 300 \mathrm{~m}$ the field which could have been potential sources of inoculum were located and destroyed. In May 1990, the number of cankers on each tree was determined.

In March 1991, the Royal trees were removed and the experiment was repeated in the same orchard using 1-year-old trees of cv. Ennis planted in 8-liter pots containing a commercial growth medium (18). Potted trees were positioned in five $150-\mathrm{m}$ rows perpendicular to the north edge of the orchard, with the first tree in each row under the canopy of the orchard; this design also was repeated in the field located south of the orchard. Both rows and trees within rows were spaced $10 \mathrm{~m}$ apart. Each Ennis tree was $1 \mathrm{~m}$ tall with $\approx 25$ buds. Trees were watered during periods without precipitation and remained in place through mid-June, when the period of ascospore release ends (19). The trees then were planted and maintained in a field at the Southwest Washington State University Research and Extension Center in Vancouver, WA until June 1992, when the number of cankers from infections the previous year was determined on each tree.

In March 1992, the experiment was conducted a third time by placing 1-year-old Royal trees in rows perpendicular to the northern edge of a 6-ha, diseased hazelnut orchard near Damascus, OR. Royal trees in 8-liter pots were positioned in eight $120-\mathrm{m}$ rows perpendicular to the north edge of the orchard, with the first tree in each row under the canopy of the orchard. Trees were spaced $10 \mathrm{~m}$ apart in rows and the rows were spaced $4 \mathrm{~m}$ apart. Woods to the south of the orchard precluded placing trees in this direction. Each tree was $1 \mathrm{~m}$ tall and had $\approx 32$ buds. On 28 May, the potted trees were moved to the United States Department of Agriculture-Agricultural Research Service (USDA-ARS) Horticultural Crops Research Unit in Corvallis, OR and maintained until July 1993, when they were evaluated for cankers.

Disease gradients for each location were determined by regression analysis (Statgraphics, version 3; Manugistics, Inc., Rockville, MD) based on $\log (y)=b \log (x)+c$, where $y$ is the number of cankers per tree, $x$ is the distance (meters) from the edge of the orchard, and $b$ and $c$ are the slope and $y$-intercept regression parameters, respectively (11). In addition, the numbers of cankers on each tree at each distance from the orchard were analyzed with analysis of variance (ANOVA) to identify significant effects of tree position on disease severity.

Disease increase in a commercial orchard. To study directional increase of eastern filbert blight, disease progress was followed in an orchard in northern Clackamas Country, OR that was isolated from other orchards known to contain diseased hazelnut trees. This 20-ha orchard was composed of mature trees of moderately resistant $\mathrm{cv}$. Barcelona interplanted with trees of highly susceptible cv. Daviana as a pollenizer (6\% of trees). In August 1988, 13 diseased trees were found near the center of the orchard in a 0.08-ha area (12). Based on the number of rows of stromata on cankers, the tree initially infected was identified and estimated to have been diseased for 3 years. Subsequently, each winter from 1989 to 1992 , all trees in the orchard were inspected from the ground and selected trees were inspected from a pruning tower for incidence of eastern filbert blight. Because of the constraints of time and labor, the tower survey was limited to all Daviana trees and all trees that were within $18 \mathrm{~m}$ (three trees) of any diseased tree. This method proved effective for detecting cankers in a previous survey (21). When detected, diseased branches were pruned and destroyed.

To analyze the directional spread of eastern filbert blight, the orchard was divided into $90^{\circ}$ sectors by compass direction centered on the tree with the oldest canker: northern (316 to $45^{\circ}$ ), eastern $\left(46\right.$ to $\left.135^{\circ}\right)$, southern $\left(136\right.$ to $\left.225^{\circ}\right)$, and western (226 to $315^{\circ}$ ) sector. Each sector contained 900 to 1,500 trees. Diseased trees in the orchard were mapped by location and by the year that cankers were first detected. Disease progress in each sector was determined with polynomial regression models of cumulative proportion of diseased trees in each sector during the 4 years. The area under the disease progress curve (AUDPC) value was calculated for each sector.

Disease spread in mini-orchards. A 5-year study was conducted in Columbia County, OR to monitor temporal and spatial disease increase in 12 121-tree mini-orchards of European hazelnut planted with cultivars with differing levels of host resistance $(4,18)$. Five cultivar arrangements were evaluated with the pollenizers interplanted at either $12 \%$ (corners of 4-by-4 tree grid pattern) or $6 \%$ (corners of 6-by-6 tree grid pattern). Treatments were: Ennis with $12 \%$ Butler as pollenizer (both highly susceptible), Barcelona with $12 \%$ Hall's Giant as pollenizer (both moderately resistant), Barcelona with Daviana as pollenizer (highly susceptible) interplanted at both 12 and 6\%, and Casina with $12 \%$ Tonda Romana as pollenizer (both moderately susceptible). A sixth treatment was established to evaluate the effect of fungicide applications on disease increase in mini-orchards planted with Ennis and $12 \%$ Butler. Each treatment was replicated with two miniorchards in an 8-ha pasture. Replicates consisted of mini-orchards of the six treatments arranged in a row in the east-to-west direction with $15 \mathrm{~m}$ between mini-orchards. Replicates were separated by $140 \mathrm{~m}$ in the north-to-south direction. Treatments were randomized in each replicate. Two-year-old trees obtained from commercial nurseries were planted in 11-by-11 arrangements with an inter-tree spacing of $3 \mathrm{~m}$; each mini-orchard occupied 0.1 ha. Mini-orchards of Ennis and Barcelona were established in February 1989. Because of limited tree availability in 1989, the planting of mini-orchards of Casina and Tonda Romana was delayed until February 1990.

A line source of inoculum was established by planting healthy trees of cv. Royal, highly susceptible to eastern filbert blight, in a row along the south edge of each mini-orchard in February 1989. In February 1991, epidemics were initiated by transplanting 22 4-year-old diseased trees of cv. Butler with sporulating cankers into the row of Royal trees on the south edge of each mini-orchard (i.e., two diseased Butler trees between adjacent Royal trees). These diseased Butler trees were 1 to $1.5 \mathrm{~m}$ tall and had an average of 2.8 cankers per tree.

In the two mini-orchards assigned fungicide treatments, two to three fungicide applications were applied in the period from lateMarch to late-April during the 1991 to 1994 seasons. All applications were applied with a motorized tank sprayer equipped with handgun; sprays were applied to near runoff at volumes that ranged from 2 to 6 liters per tree, depending on tree size. In 1991, applications of fenarimol (Rubigan $1 \mathrm{EC}, 31.3 \mathrm{ml} / \mathrm{liter}$ ) were made on 11 (leaf emergence) and 23 April (early shoot elongation). In 1992 to 1994, chlorothalonil (Bravo 720, $187 \mathrm{ml} /$ liter) was applied at budbreak (24, 18, and 24 March in 1992, 1993, and 1994, respectively), followed by chlorothalonil mixed with fenarimol at leaf emergence (7, 7, and 5 April in 1992, 1993, and 1994, respectively), and by fenarimol at the beginning of shoot elongation (21, 30, and 20 April in 1992, 1993, and 1994, respectively). 
Disease progress data were recorded annually during the winters of 1992 to 1995 . Each year, the number and length of cankers were determined on each tree in each mini-orchard. In addition, total branch length was estimated for five main cultivar trees and two pollenizers selected at random in each mini-orchard. Disease severity (proportion of total branch length cankered) was calculated by dividing the canker length on each tree by the average total branch length on trees of the same cultivar. Disease progress for different cultivar arrangements was compared graphically by plotting average disease severity in each row as the dependent variable and the distance from the source and time as the independent variables. An AUDPC for each mini-orchard was estimated from the equation derived from regressing the logit of mean proportion of branch length cankered each year on the year of observation. Disease gradients for each mini-orchard were determined each year based on $\log (y)=b \log (x)+c$, where $y$ is the proportion of the branch length with cankers and $x$ is the distance from the inoculum row.

Two analyses were conducted to evaluate the relative contribution of main crop and pollenizer cultivars to the epidemic. First, disease severity on each pollenizer tree in a mini-orchard was compared to a randomly selected adjacent main cultivar tree in the same row. Paired $t$ test analyses were used to determine whether there were differences in proportional severity among paired main and pollenizer trees in each mini-orchard. Second, the mean disease severity of all trees in rows containing pollenizers and of only main cultivar trees in rows containing pollenizers was compared with the mean disease severity in the immediately adjacent rows that did not contain pollenizers. Data for each row in each mini-orchard were pooled over the two replicates for each pollenizer-main crop cultivar combination and over years. Twoway ANOVA was used to determine if the two measures of mean disease severity in the pollenizer rows differed significantly from the mean disease severity in adjacent rows and whether there was an interaction between row position and year of observation. The relative susceptibility of pollenizer cultivars also was compared using a paired $t$ test analysis of the number of cankers on pollenizer trees located in the same relative locations in each miniorchard.

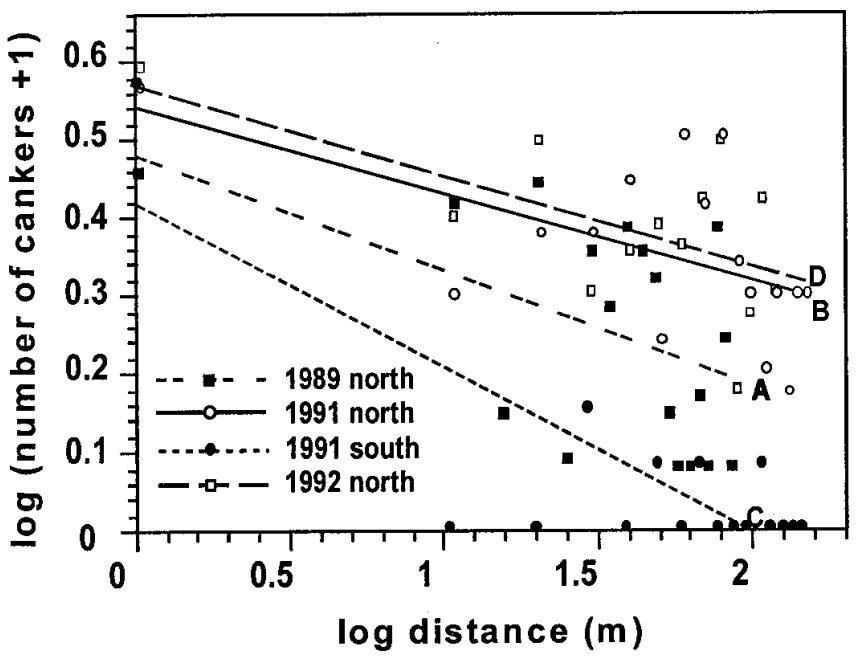

Fig. 1. Severity of eastern filbert blight in 2-year-old European hazelnut trees exposed to inoculum of Anisogramma anomala at varying distances from mature, severely diseased orchards. Trees were exposed at the age of 1 year for 3 months beginning at bud break. Cankers on each tree were counted after 18 months of incubation. Regression lines and points represent $\mathbf{A}, 0$ to $90 \mathrm{~m}$ north of an orchard in Multnomah County, Oregon in 1989 $(b=-0.154), \mathbf{B}, 0$ to $150 \mathrm{~m}$ north $(b=-0.111)$, and $\mathbf{C}$, south $(b=-0.208)$ of the same orchard in 1991, and D, 0 to $120 \mathrm{~m}$ north $(b=-0.119)$ of an orchard in Clackamas County, OR in 1992. Regression lines labeled A, B, and D were not significantly different $(P>0.05)$ from zero.
Ascospore dispersal gradients. In 1993 and 1995, experiments were conducted to determine the concentration of airborne ascospores of A. anomala dispersing from hazelnut orchards that contained severely diseased trees. Both studies employed AGI-30 liquid impinger air samplers (Ace Glass Inc., Vineland, NJ) placed on towers located north (downwind) of the orchards (15). Samplers were mounted on rotating platforms equipped with a tail fin that continuously oriented the sampler orifice into the direction of the wind. A single vacuum pump (Model 0523-U4F-6582DX; Cast Corp., Benton Harbor, MI), powered by a portable electric generator, provided vacuum to sets of two to three samplers. The vacuum lines were 10-mm-diameter polyethylene tubing (Raindrip Co., Simi Valley, CA) from the pump to the tower, and 10-mm-diameter Tygon tubing (Norton Performance Plastic Corp., Akron, $\mathrm{OH}$ ) from the tower to the samplers. Each sampler drew air at the rate of 10 liters min $^{-1}$.

During major rain events, platforms with samplers were raised to predetermined elevations with a pulley system. At the start of a sampling period, $30 \mathrm{ml}$ of a $0.05 \% \mathrm{CuSO}_{4}$ solution was placed in each sampler, the vacuum system was turned on, and the rate of air intake of each sampler was measured with a manometer (Burkhard Scientific, Rickmansworth, Hertfordshire, England). At the end of a sampling period, the intake tube was rinsed into the sampler's collection reservoir to recover spores adhering to walls of the tube. In the laboratory, the liquid from each sampler was filtered through a $(0.8-\mu \mathrm{m}$-pore-size $)$ gridded filter, and the concentration of ascospores of $A$. anomala in each sample was determined by counting spores in 15 grids on each filter as described previously (19).

The 1993 study was conducted adjacent to a 40-year-old, 10-ha orchard (cvs. Barcelona and Daviana) located near Damascus, OR. Trees were 5 to $6 \mathrm{~m}$ tall and had 20,50, and $30 \%$ of the sporulating cankers on branches below $2.5 \mathrm{~m}$, between 2.5 and $4.5 \mathrm{~m}$, and above $4.5 \mathrm{~m}$ in the canopies, respectively. Towers were placed between two trees at the edge of the orchard $(0 \mathrm{~m})$ and 5 , 15,30 , and $60 \mathrm{~m}$ north of the orchard, such that southern winds passed over the orchard before reaching the samplers. On each tower, samplers were placed at heights of 1.25 and $5 \mathrm{~m}$, which represented the bottom and top of the canopy, respectively. Towers at the edge and 5 and $15 \mathrm{~m}$ from the orchard also had a sampler placed at $2.5 \mathrm{~m}$ (middle of canopy). Ascospores were collected during nine periods of rain from 3 March to 17 April. Wind speed and direction $3 \mathrm{~m}$ above the canopy $(8 \mathrm{~m})$ and precipitation were recorded with an anemometer (Model 14A; Met-One, Grants Pass, OR) and a tipping bucket rain gauge (Model TE525; Texas Electronic, Dallas), respectively, connected to a datalogger (Model CR21X; Campbell Scientific Inc., Logan, UT).

The second study was conducted in March 1995 at the miniorchard site in Columbia County using the same equipment and techniques described above. Tree height was 2.5 to $3.5 \mathrm{~m}$ and trees had $70 \%$ of sporulating cankers located between 1 to $2 \mathrm{~m}$ of elevation, and $30 \%$ above $2 \mathrm{~m}$. Towers were placed at 5,10 , and $20 \mathrm{~m}$ from the north of the edge of one of the mini-orchards of $\mathrm{cv}$. Ennis. Samplers were placed at heights of 1.25, 2.5, 4, 5.5, and $7 \mathrm{~m}$ on the two towers closest to the orchard, and at elevations of $1,2.5,5$, and $7 \mathrm{~m}$ on the third tower. An impinger sampler and a Burkhard spore trap (Burkhard Scientific) also were placed in the center the mini-orchard, with trap orifices set at $1.5 \mathrm{~m}$ (midcanopy). Wind speed and direction at $4 \mathrm{~m}$ above the canopy $(7 \mathrm{~m})$ and precipitation were recorded as described above. Because of the small orchard size ( 33 by $33 \mathrm{~m}$ ), samplers placed a distance of $20 \mathrm{~m}$ downwind from the mini-orchard did not capture spores unless wind moved directly over the mini-orchard. Thus, data were analyzed for 2 days only ( 8 and 9 March) because on other days the wind direction was not parallel to the line of samplers.

Ascospore aerial concentration profiles. Observed ascospore recovery data were analyzed by calculating the relative number of spores collected in each trap during each sampling period. The 
relative number of spores was defined as the number of spores collected in a trap divided by the number caught in the trap located at a height of $1.25 \mathrm{~m}$ within the canopy, where the highest spore counts were observed. Relative spore data were combined over the sampling dates. Relative concentration gradients of ascospores were estimated at each trap elevation by plotting relative concentration versus the distance that spore-sampling towers were placed downwind from the orchard edge.

Observed ascospore capture data from the dispersal experiments were compared graphically with profiles of expected ascospore concentrations derived from a model that describes movement of ascospores of Venturia inaequalis within and away from apple orchards (2). Important to this study, the $V$. inaequalis model assumes that ascospores are released into the air during periods of rain (2) and predicts downwind diffusion of ascospores based on an input of wind speed. Thus, actual ascospore profiles of $A$. anomala contrasted against those expected for $V$. inaequalis provides a comparative benchmark on the relative dispersal capability of the eastern filbert blight pathogen.

To evaluate the $V$. inaequalis model for $A$. anomala, timeaveraged horizontal wind speed $\left(U, \mathrm{~m} \mathrm{~s}^{-1}\right)$ and wind turbulent diffusivity $\left(K, \mathrm{~m}^{2} \mathrm{~s}^{-1}\right)$ were estimated from the wind speed data measured at the site following methods described previously by Aylor (2). Using these estimates, the finite-difference model equations were solved numerically for ascospore concentration $(C$, ascospores $\mathrm{m}^{3}$ ) at all vertical distances from 0 to $30 \mathrm{~m}$ and horizontal distances from 0 to $32 \mathrm{~m}$ downwind from the source. In these analyses, values of $C$ at the upwind edge of the source were set equal to zero (no other immediate sources in the area) and ascospores were introduced at several heights in the canopy scaffolding at a rate $Q$ (ascospores $\mathrm{m}^{2} \mathrm{~s}^{-1}$ ) per unit area. Because actual values of $Q$ could not be estimated from the data, $Q$ was arbitrarily set to a biologically realistic constant. Modeled relative ascospore aerial concentration profiles were computed for distances corresponding to the placement of the spore sampling

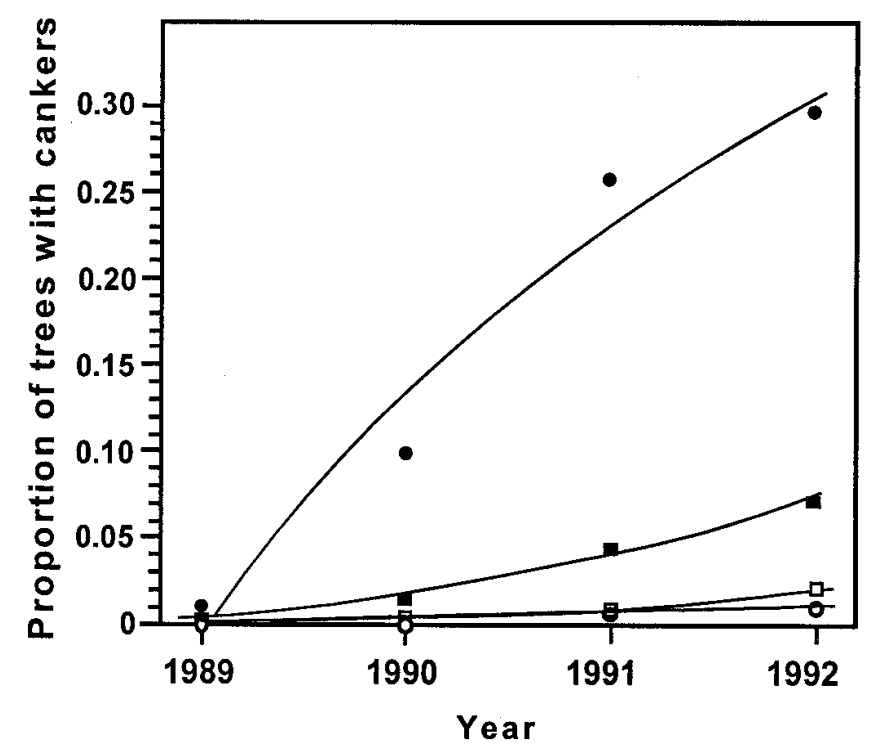

Fig. 2. Directional increase of eastern filbert blight in a 20-ha European hazelnut orchard located in Clackamas County, OR. The orchard was composed of the moderately resistant cv. Barcelona interplanted with the highly susceptible pollenizer cv. Daviana. Disease was first found in a contiguous group of 13 trees near the center of the orchard in August 1998. Trees were inspected for cankers of eastern filbert blight in the winters of 1989 to 1992. Lines depict increase in disease incidence within directional $90^{\circ}$ sectors emanating from the tree with oldest detected canker: northern sector between $316^{\circ}$ and $45^{\circ}$ containing $\approx 1,500$ trees $(\bullet)$; eastern sector between $46^{\circ}$ and $135^{\circ}$ with $\approx 1,300$ trees $(\mathbf{\square})$; southern sector between $136^{\circ}$ and $225^{\circ}$ with $\approx 1,150$ trees $(\square)$; and eastern sector between $226^{\circ}$ and $315^{\circ}$ with $\approx 900$ trees $(\mathrm{O})$. towers used in the experiment, and compared to the observed relative ascospore concentration profiles.

Regional weather patterns. Weather data were analyzed from 1974, when the eastern filbert blight was established in Clark County WA, through 1995. Rainfall and wind data were collected from National Weather Service records (EarthInfo Inc., Boulder, $\mathrm{CO}$ ) from the Portland International Airport, the Hillsboro Airport, and McNary airfield in Salem. The Portland airport is located near the Washington border and is indicative of Clark County and the region east of Portland where, in 1986, eastern filbert blight was first detected in Oregon. The Hillsboro Airport is located in the Tualatin Valley, a major hazelnut production area and $\approx 50 \mathrm{~km}$ west of the site of the 1986 detection. The Salem airport is located in the center of the Willamette Valley, $\approx 60 \mathrm{~km}$ south of the 1986 detection site and $15 \mathrm{~km}$ south of the known range of the disease. For each year, rain events $10 \mathrm{~h}$ or more in duration during the period from 1 March to 1 June were selected from the weather data (19). For each rain event, the recorded wind direction for each hour of an event was tabulated into eight categories by compass direction: 0 to $45^{\circ}, 46$ to $90^{\circ}, 91$ to $135^{\circ}, 136$ to $180^{\circ}, 181$ to $235^{\circ}, 236$ to $270^{\circ}, 271$ to $315^{\circ}$, and 316 to $360^{\circ}$.

\section{RESULTS}

Disease gradient experiments. Over the three experiments, $76 \%$ of 1-year-old trees placed up to $150 \mathrm{~m}$ north of the mature, diseased orchards became infected with an average of 1.3 to 1.8 cankers per tree. The disease gradient north of the orchard was very shallow (Fig. 1), with slopes that were not significantly different $(P>0.10)$ from zero. In the one experiment in which trees also were placed south of the orchard, single cankers were found on only five trees (5\%), an average of 0.07 cankers per tree. The disease gradient south of the orchard was significantly $(P<$ 0.05) steeper than zero. Based on ANOVA, significant differences were not detected $(P>0.10)$ in incidence of cankers among trees placed at the edge of the orchard and those placed at distances of $\geq 5 \mathrm{~m}$ north of the orchard, but the same comparison made to the

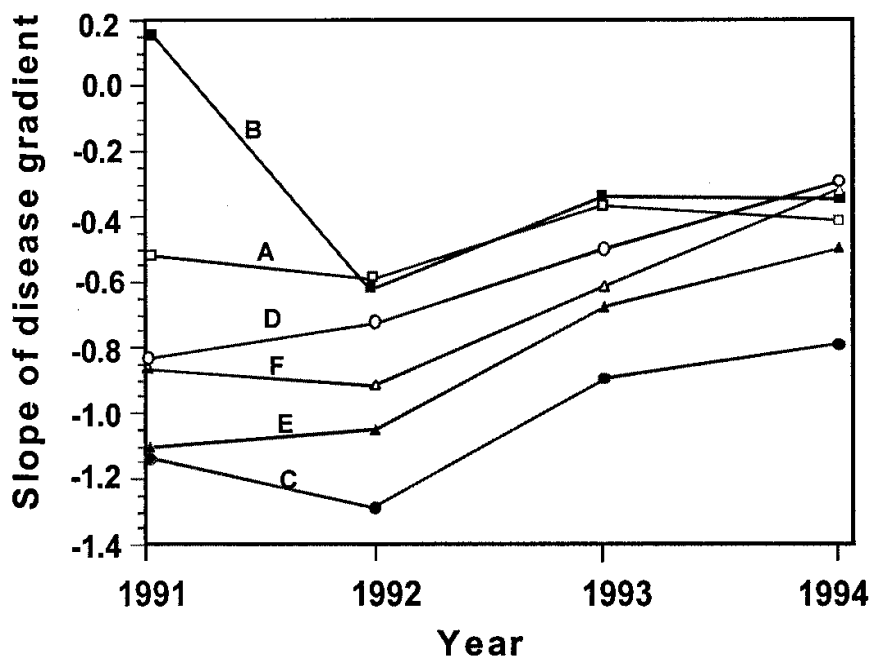

Fig. 3. Change in the slope of disease gradients from 1991 to 1994 measured in a 121-tree mini-orchard of different main crop cultivar and pollenizer cultivar arrangements of European hazelnut and application of fungicides. Orchards were planted in winter 1989, and a row of diseased trees was transplanted along the windward edge of each mini-orchard in winter 1990. Slopes of disease gradients are based on $\log (y)=b \log (x)+c$, where $y$ is the number of cankers per tree, $x$ is the distance $(\mathrm{m})$ from the edge of the orchard, and $b$ and $c$ are the slope and $y$-intercept regression parameters, respectively. Cultivar arrangements were: A, Ennis interplanted with $12 \%$ Butler as the pollenizer $(\square)$; B, Ennis interplanted with $12 \%$ Butler with biweekly fungicide application (ם); C, Barcelona interplanted with $6 \%$ Daviana (O); D, Barcelona interplanted with $12 \%$ Daviana $(\bullet)$; E, Barcelona interplanted with $12 \%$ Hall's Giant $(\Delta)$; and F, Casina interplanted with $12 \%$ Tonda Romana $(\boldsymbol{\Delta})$. 
south showed that significantly more cankers occurred at the edge of the orchard than at distances of $\geq 10 \mathrm{~m}$.

Disease increase in a commercial orchard. Increase of eastern filbert blight was most rapid in the northern orchard sector, as illustrated in an aerial photograph taken in 1990 (12). By the fourth year, $30 \%$ of $\approx 1,500$ trees in the northern sector $(N)$ had become disease compared with less than $7 \%$ of $\approx 1,300$ trees in the eastern $(\mathrm{E}), 2 \%$ of $\approx 1,150$ trees in the southern $(\mathrm{S})$, and $1 \%$ of $\approx 900$ trees in the western (W) sectors (Fig. 2). The AUDPC values were $0.531,0.065,0.0193$, and 0.013 for $\mathrm{N}, \mathrm{E}, \mathrm{S}$, and W sectors,
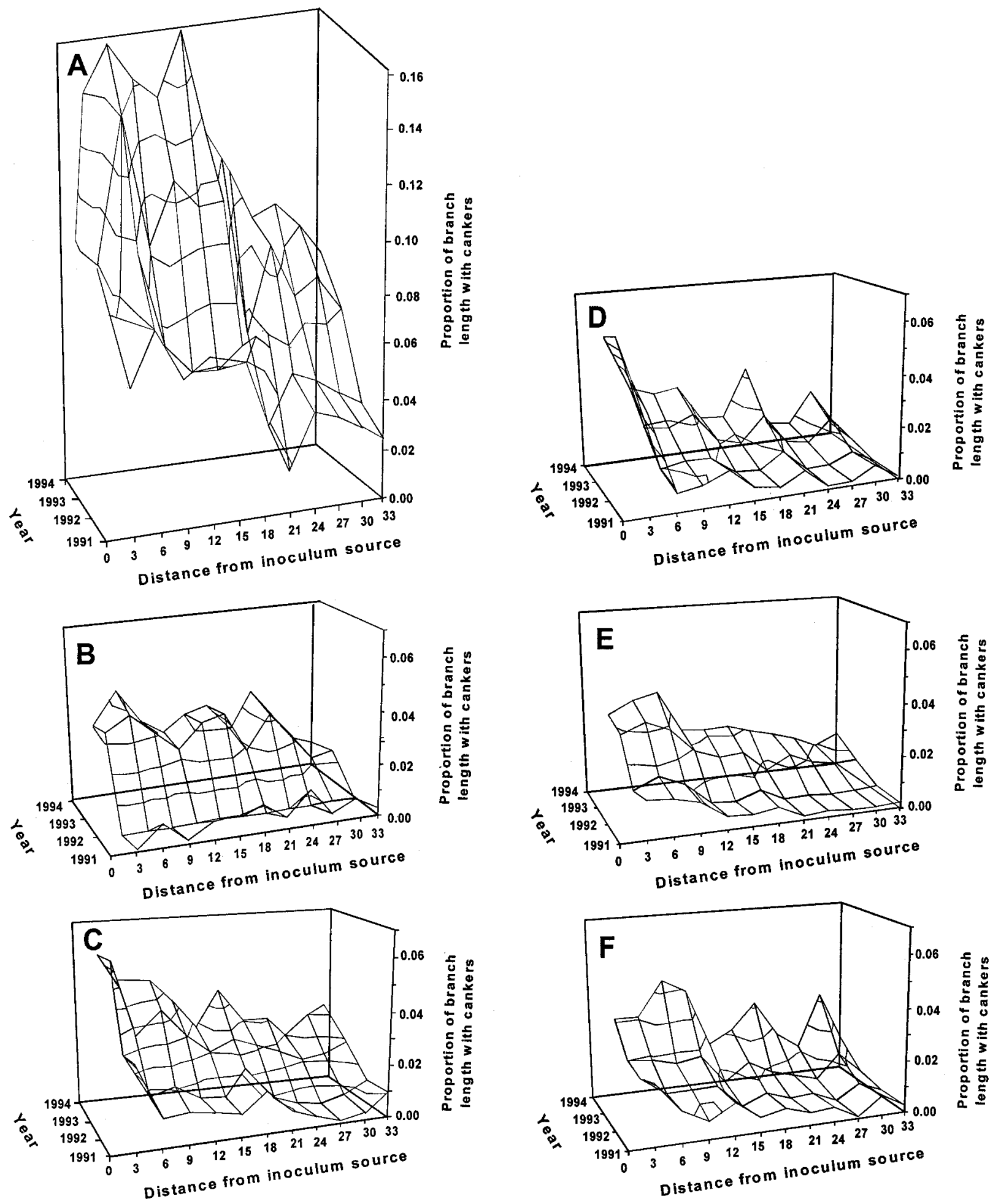

Fig. 4. Epidemics of eastern filbert blight in European hazelnut as affected by cultivar and fungicide applications. Trees were planted on 11-by-11 grids on 3-m centers in February 1989. In February 1990, 2-year-old trees with sporulating cankers were planted in the southernmost row ( $0 \mathrm{~m})$ to serve as an inoculum source. The number and length of cankers on each tree were recorded in 1991 to 1994 and the proportion of the total branch length with cankers was calculated. Main cultivars were interplanted with $6 \%$ pollenizers (corners of 6-by-6 tree grid pattern) or $12 \%$ pollenizers (corners of a 4-by-4 grid pattern). Planting arrangements were A, Ennis with 12\% Butler; B, Ennis with 12\% Butler and fenarimol or chlorothalonil applied at 2-week intervals following bud break; C, Barcelona with 6\% Daviana; D, Barcelona with 12\% Daviana; E, Barcelona with 12\% Hall's Giant; and F, Casina with 12\% Tonda Romana. In mini-orchards with $12 \%$ pollenizers, pollenizers were in rows $3,12,21$, and $30 \mathrm{~m}$ from the inoculum source row; in the plantings with $6 \%$ pollenizers, they were 3,18 , and $33 \mathrm{~m}$ from the inoculum row. 
respectively. The distribution of diseased trees was highly contagious, with $98 \%$ of diseased trees located in a $90^{\circ}$ sector of the orchard between $330^{\circ}$ and $60^{\circ}$ and $88 \%$ of the diseased trees in these areas were within $5 \mathrm{~m}$ of another diseased tree. In this sector, the incidence of disease was high in both Barcelona $(65 \%)$ and Daviana (69\%) trees. In area of the orchard with low disease incidence, disease was most commonly found in Daviana trees.

Disease spread in hazelnut mini-orchards. Diseased trees were observed in all 11 rows of each mini-orchard 1 year after introduction of the inoculum source trees. In contrast to the disease gradients measured in a northern direction from mature orchards, the slopes of most disease severity gradients measured in miniorchards over the 4-year period were significantly steeper than zero $(P<0.05)$ (Fig. 3). In 1990, disease gradients were steepest in Barcelona mini-orchards with 12\% Daviana or 6\% Hall's Giant pollenizers ( $b=-1.138$ and -1.109 , respectively) and shallowest in the Ennis-Butler mini-orchards with and without fungicide applications ( $b=0.169$ and -0.525 , respectively) (Fig. 3). During the 4-year observation period, disease gradients became progressively less steep in all cultivar arrangements except the EnnisButler mini-orchard, in which the gradients varied little between years (Fig. 3).

Disease increase in mini-orchards was affected by the cultivars (Fig. 4). Ennis had the greatest mean number of cankers per tree, ranging from 6.1 to 11.6 over the 4 years (Fig. 5). The total length of cankers in mini-orchards was four times greater on Ennis trees than on the other cultivars throughout the study. In contrast, Barcelona and Casina ranged from 0.9 to 4.3 cankers per tree (Fig. $5)$. The rate of canker expansion during the first 2 years was greater in Ennis and Butler trees, averaging 26.6 and $25.4 \mathrm{~cm} /$ year, respectively, than in the other cultivars, for which canker length expanded at rates of 14.5 to $17.9 \mathrm{~cm} /$ year. Cankers coalesced after several years and individual cankers were difficult to discern. The mean AUDPC value for Ennis-Butler mini-orchards was three to five times greater (0.069) than the mean AUDPC values measured in Barcelona mini-orchards with $12 \%$ Daviana (0.024), $6 \%$ Daviana (0.017), 12\% Hall's Giant (0.013), and the Casina-Tonda Romana mini-orchard (0.018) $\left(R^{2}=0.75\right.$ to 0.93 for regression equations).

The relative susceptibility of main crop and pollenizer cultivars varied among orchard combinations. For Ennis-Butler miniorchards over all years, higher numbers of cankers (Fig. 5) and greater total canker lengths (Fig. 6) were measured on Ennis compared with its pollenizer. In contrast, the pollenizer cultivar Daviana showed greater susceptibility than the main cultivar, Barcelona (Figs. 4 and 5), but the difference narrowed over the 4-year period (Fig. 6). Because Daviana was more susceptible than Barcelona, rows containing pollenizers (i.e., in Fig. 4, the rows 3, 12,21 , and $30 \mathrm{~m}$ from the inoculum row in $12 \%$ Daviana and 3 , 18 , and $33 \mathrm{~m}$ in $6 \%$ Daviana arrangements) had higher average levels of disease $(P>0.05)$ than corresponding adjacent rows. Comparisons of the mean disease severity on Barcelona trees located in pollenizer rows with Daviana were similar to the mean severities in adjacent rows of Barcelona, also indicating that the higher disease severity in the pollenizer rows was due to greater disease in the pollenizer cultivar. Similar patterns were observed in Casina-Tonda Romana mini-orchards, with Tonda Romana showing greater susceptibility $(P>0.05)$ than Casina (Fig. 4). In Barcelona-Hall's Giant mini-orchards, measured disease severities on two cultivars were similar during the 4 years (Figs. 4 and 6). Comparisons of the number of cankers in the different pollenizer cultivars at similar locations in each mini-orchard showed that Hall's Giant trees had a significantly lower probability of becoming infected compared with Daviana trees (Fig. 5).

Applications of fungicides in Ennis-Butler mini-orchards reduced disease severity compared with the nontreated mini-orchards (Fig. 4), with AUDPC values of 0.026 and 0.069, respectively. During the first 2 years, the number of cankers per tree in mini-orchards treated with fungicides was less than the number in nontreated mini-orchards (Fig. 5). The progress of the epidemic in the EnnisButler mini-orchard treated with fungicides was similar to that observed in Barcelona and Casina mini-orchards (Fig. 4).

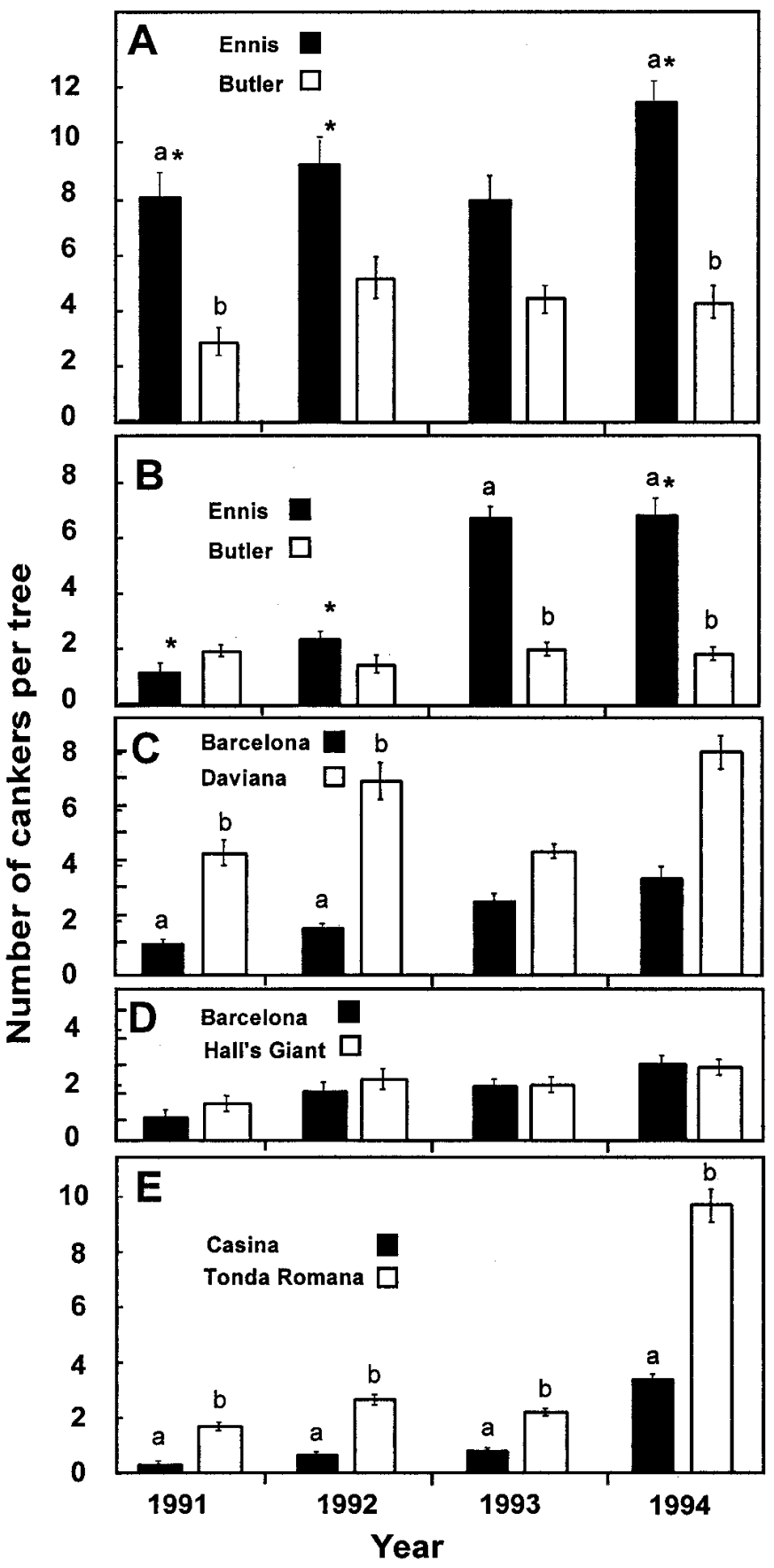

Fig. 5. Comparison of the number of eastern filbert blight cankers per tree in main cultivars and pollenizer cultivars of European hazelnut in plantings in Columbia County, OR. Plantings were 0.1 ha in area, with trees planted on 3-m spacing and pollenizers planted on corners of a 4-by-4 tree grid pattern (12\%). Pollenizer-main cultivar combinations were A, Ennis-Butler; B, EnnisButler with fungicide applications; C, Barcelona-Daviana; D, BarcelonaHall's Giant; and E, Casina-Tonda Romana. Comparisons were made for each pollenizer tree and an adjacent main crop tree in the same row. Significant differences $(P>0.01)$ between the number of cankers on pollenizer and main crop trees in each year according to $t$ tests are denoted by different letters above the columns. Significant differences $(P>0.01)$ between number of cankers each year on Ennis or Butler A, with or $\mathbf{B}$, without fungicide applications are denoted by an asterisk. Vertical bars represent standard error of the mean. 
Ascospore dispersal gradients. In 1993, ascospores were collected during nine rain events scattered over a period of 6 weeks. Weather conditions varied during the collection periods, with average wind speeds above the canopy ranging from 2.3 to $4.7 \mathrm{~m} \mathrm{~s}^{-1}$ and the mean precipitation ranging from 0 to $8.9 \mathrm{~mm}$ during the sampling periods and from 0.5 to $4.7 \mathrm{~mm}$ during the previous $16 \mathrm{~h}$. The mean wind direction during the sampling periods was parallel to the line of spore traps $\left(180^{\circ} \pm 24^{\circ}\right)$. No rain was recorded during four sampling periods. Across all traps, however, the mean concentration of ascospores in the air was not different $(P=0.87)$ between sampling periods with measurable rain $\left(142 \mathrm{spores} / \mathrm{m}^{3}\right)$ and periods without rain $\left(133 \mathrm{spores} / \mathrm{m}^{3}\right)$. The absolute number of ascospores captured during each rain event declined steadily over the 6-week period from early March to midApril (20). In contrast, for the mini-orchard experiment conducted in 1995, the absolute numbers of spores collected on 8 and 9 March were similar, averaging 206 and 237 ascospores $\mathrm{m}^{-3} \mathrm{~h}^{-1}$, respectively. Rain events in the mini-orchard also were more consistent than in the 1993 experiment. Rain accumulations were $6 \mathrm{~mm}$ during the two sampling periods, and 12 to $24 \mathrm{~mm}$ during the previous $16 \mathrm{~h}$. Mean wind speed above the canopy in the mini-orchard averaged 2.1 and $5.3 \mathrm{~m} \mathrm{~s}^{-1}$ on 8 and 9 March, respectively.

Relative gradients of ascospore concentration downwind from the edge of the orchard also differed between the two sites. In the mature orchard, the observed relative gradients were shallow, such that spore concentrations in the most distal traps $(60 \mathrm{~m})$ averaged 60 to $70 \%$ of the capture in traps located at the orchard edge (Fig. 7A). In contrast, the relative capture of ascospores downwind of the young 0.1-ha orchard (Fig. 7B) varied more in both vertical and horizontal distances. For example, relative ascospore concentration at a distance of $5 \mathrm{~m}$ from the orchard edge was greatest at heights of 1.25 (0.97) to $2.5 \mathrm{~m}(0.43)$, the height of most of the cankers in the orchard, but low at heights above the canopy (Fig. 7B). Moreover, at elevations of 1.25 and $2.5 \mathrm{~m}$, gradients of

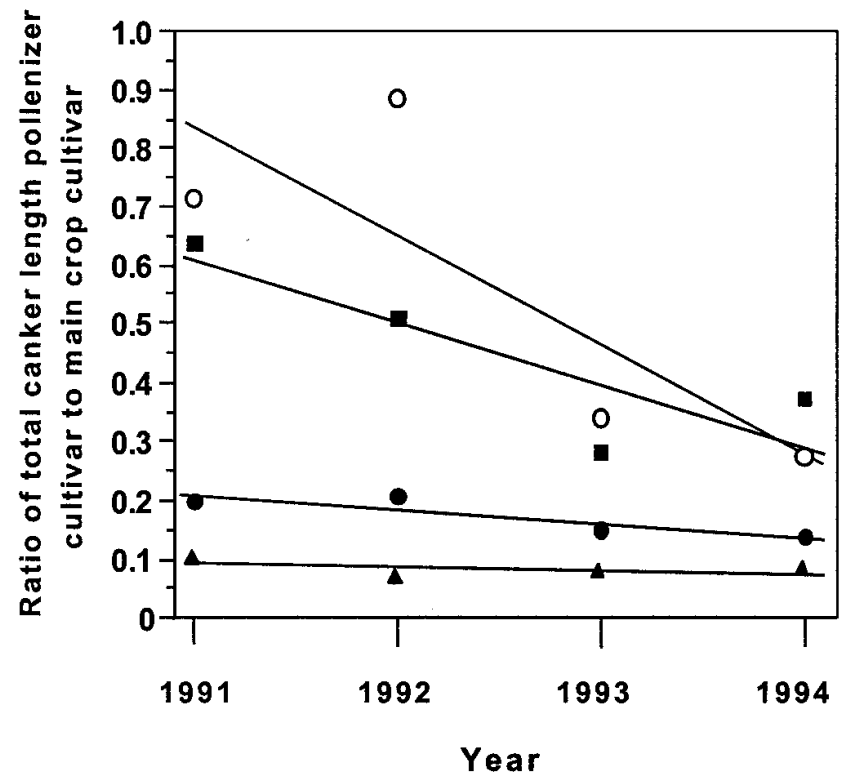

Fig. 6. Relative contributions of pollenizer and main cultivars to the epidemic of eastern filbert blight in mini-orchards of European hazelnut grown in western Oregon. Orchards were 0.1 ha in area with trees planted on 3-m spacing. Pollenizers were planted at the corners of 4-by-4 tree grid pattern (12\% of orchard). Pollenizer-main cultivar combinations were Daviana-Barcelona (O), Hall's Giant-Barcelona (•), Tonda Romana-Casina $(\boldsymbol{\square})$, and Ennis-Butler ( $\boldsymbol{\Delta})$. Lines represent regression relationships derived from mean ratios of total canker length on pollenizers to main cultivars. Only the lines representing Daviana-Barcelona and Tonda Romana-Casina had slope coefficients that were significantly greater than zero $(P<0.05)$. relative ascospore concentration declined steeply as distance increased to $20 \mathrm{~m}$ downwind from the orchard edge. Conversely, relative ascospore concentration at the 5- and 7-m elevations increased from $2 \%$ at $5 \mathrm{~m}$ downwind to approximately $20 \%$ at $20 \mathrm{~m}$ downwind from the orchard edge (Fig. 7B).

Relative ascospore concentrations calculated from the $V$. inaequalis dispersal model resulted in gradients comparable to the gradients observed for $A$. anomala. Like the observed gradients (Fig. 7A), the modeled spore gradients (Fig. 7B) were relatively shallow, with concentrations at the 60 -m distance averaging $\approx 60 \%$ of the capture at the orchard edge. For the 0.1-ha mini-orchard, both modeled (Fig. 7D) and observed (Fig. 7B) spore concentrations at heights of 1.25 and $2.5 \mathrm{~m}$ declined with distance downwind from the orchard, but increased gradually at elevations above the canopy ( 5 and $7 \mathrm{~m}$ ) as distance from the orchard increased. At the 20-m distance, however, the observed spore concentrations in the mini-orchard were similar among all sampled elevations, whereas the model predicted that relative spore concentrations at $20 \mathrm{~m}$ would show greater vertical variation.

\section{DISCUSSION}

Over the 30-year period of the eastern filbert blight epidemic in the Pacific Northwest, the disease has moved $\approx 60 \mathrm{~km}$ from the site of initial detection. This relatively limited movement for a foliar pathogen has lead to confusion as to the dispersal biology of A. anomala and the mechanism of dispersal. For example, Gottwald and Cameron $(9,10)$ concluded that ascospores of $A$. anomala were splash dispersed, which was consistent with the slow rate of disease spread that they observed in a BarcelonaDaviana orchard under high inoculum pressure. Alternatively, growers have postulated that long-distance spread is the result of movement of the pathogen via equipment or birds. As each of these hypotheses has been examined, more attention and scientific effort has been placed on understanding the process of ascospore discharge and movement through air. This understanding has evolved to the hypothesis that, during prolonged rain events, ascospores of $A$. anomala are forcibly discharged from perithecia into the air. Arriving at this hypothesis, however, was not straightforward because, unlike many ascomycetes, the process of forcible discharge in A. anomala has not been observable in specimens bearing perithecia that have been moved from the field to the laboratory. Consequently, collection of evidence that ascospores are discharged forcibly into air has involved field studies with spore traps, and analysis of patterns of ascospore concentrations in air and of disease spread. In a previous study, $>90 \%$ of the $A$. anomala ascospores were collected by Burkhard traps during extended periods of light rain (mean rate of $0.5 \mathrm{~mm} \mathrm{~h}^{-1}$ ), conditions not conducive for splash dispersal (19). In that study, ascospores also were collected during hours in major rain events in which no precipitation was recorded. Similarly, in the current study, spore traps collected ascospores during periods immediately following rain events when branches remain wet. We also demonstrated that ascospores of $A$. anomala are easily captured in air sampled downwind from diseased trees, and that relatively shallow, primary infection gradients are observed when healthy trees are planted downwind from a large inoculum source.

In contrast to observations by Gottwald and Cameron (9), we documented rates of disease spread through mini-orchards that appear to be inconsistent with movement of spores mainly by splash. In general, dispersal by splash mechanisms is localized to distances of a few meters (14). For A. anomala, splash dispersal may account for disease spread within the canopy of hazelnut trees, but does not explain the shallowness of disease gradient observed in our experiments. Both the disease gradient and miniorchard experiments demonstrated that ascospores are dispersed readily from plantings of diseased trees. The concentration of ascospores in the air downwind from the mini-orchard showed both 
vertical and horizontal gradients away from the orchard. By contrast, for the experiments conducted in the larger, mature orchards, no significant gradients were observed in the incidence of disease either in the young sentinel trees or for the concentration of ascospores collected in the spore samplers. The difference in results between the studies may be due to the relative strength of the inoculum source and the height of spore release. In the mini-orchard study, the experimental trees were at the approximate elevation of the small line source of relatively low inoculum strength, with most of the spore samplers positioned well above the height of spore release. Conversely, at the mature orchards, the 1-year-old experimental trees and spore samplers were at or below the elevation of spore release from the large area sources of high inoculum strength.
The size of ascospores of $A$. anomala ( 4 to 5 by 8 to $12 \mu \mathrm{m}$ ) and the apparent mechanism of discharge suggested to us that a model that describes the dispersal of $V$. inaequalis $(2,3)$ was potentially applicable to the problem of understanding the movement potential of A. anomala. Concentration gradients of ascospores of $A$. anomala measured with samplers located downwind from hazelnut orchards compared with modeled gradients of $V$. inaequalis dispersal (Fig. 7) provided a general confirmation of the hypothesized similarities in dispersal biology. Moreover, in accordance with a previous spore trapping study on A. anomala (19), the model gave reasonable estimates of the rate of ascospore release per unit area of source $(2,3)$. Extrapolating beyond the distances sampled in this study, this model for $V$. inaequalis also predicts

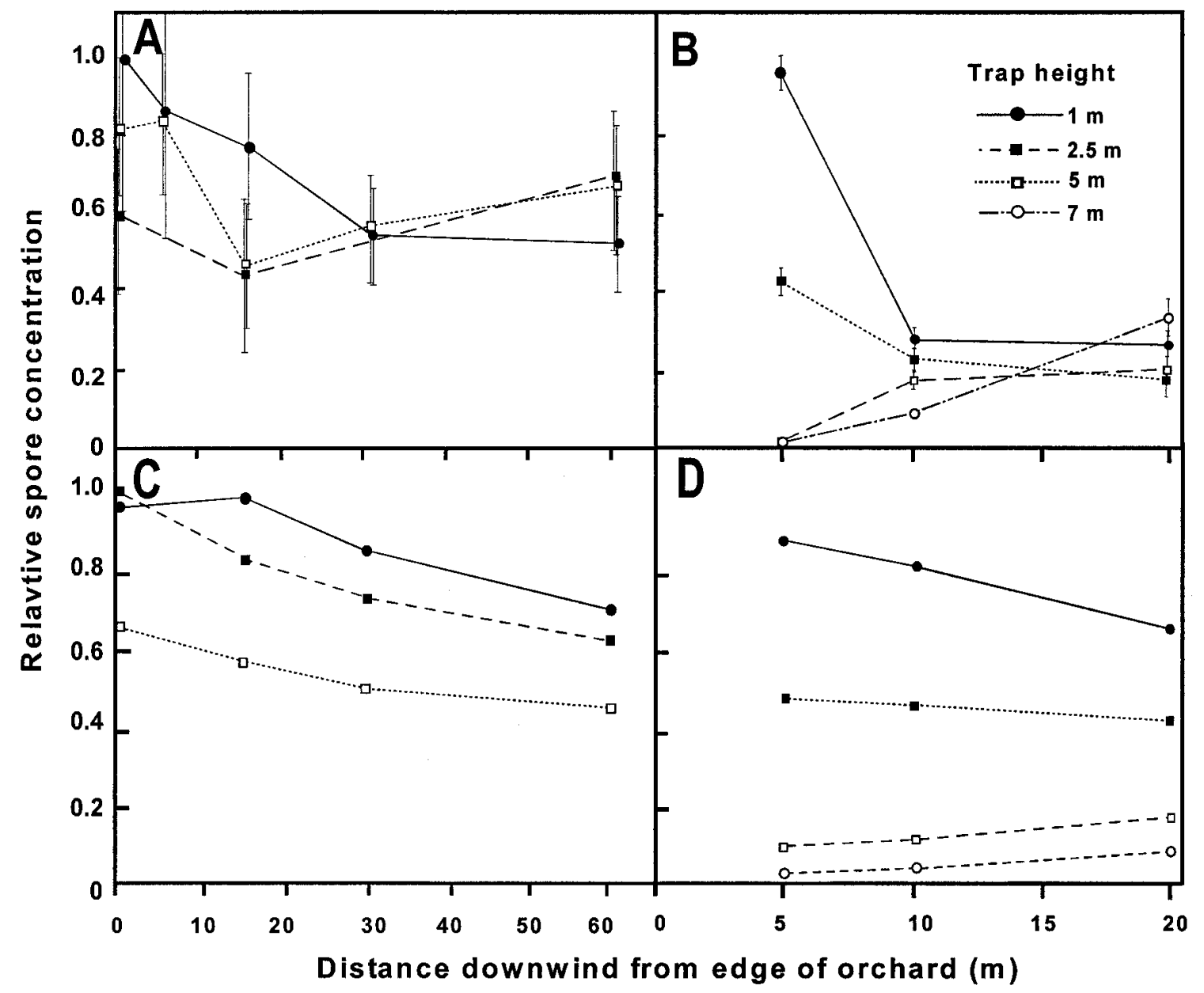

Fig. 7. Observed and modeled relative concentration of ascospores of Anisogramma anomala in the air downwind from two European hazelnut orchards severely diseased with eastern filbert blight. Ascospores were collected with liquid impinger traps during periods of extended precipitation. Traps were placed on towers at various elevations and distances north of the orchards. Modeled dispersal profiles of ascospores of A. anomala were derived from a model developed to describe the dispersal of ascospores of Venturia inaequalis from the floor of an apple orchard (2). Observed concentration gradient of ascospores downwind from A, a mature, 10-ha orchard with tree heights of $\approx 5$ to $6 \mathrm{~m}$, and $\mathbf{B}$, a 5-year-old, 0.10-ha Ennis orchard with tree heights of $\approx 2$ to $3 \mathrm{~m}$. Modeled concentration gradients ascospores downwind from $\mathbf{C}$, the mature orchard and $\mathbf{D}$, the young Ennis orchard. Vertical bars represent standard error.

TABLE 1. Wind direction in the Willamette Valley of Oregon from 1 March to 1 June during precipitation events of more than $10 \mathrm{~h}$ in duration ${ }^{\mathrm{a}}$

\begin{tabular}{|c|c|c|c|c|c|c|c|c|}
\hline \multirow[b]{2}{*}{ Recording location } & \multicolumn{8}{|c|}{ Proportion of hours with wind direction ${ }^{\mathrm{b}}$} \\
\hline & NNE & ENE & ESE & SSE & SSW & WSW & WNW & NNW \\
\hline Portland & 0.009 & 0.038 & 0.337 & 0.212 & 0.222 & 0.096 & 0.037 & 0.023 \\
\hline Hillsboro & 0.027 & 0.084 & 0.160 & 0.415 & 0.153 & 0.091 & 0.043 & 0.027 \\
\hline
\end{tabular}

a National Weather Service data were recorded at the Portland International Airport in northern Multnomah County, Hillsboro Airport in Washington County, and Salem (McNary Field) in Marion County. Data are from 1974 to 1995. Length of precipitation events was calculated from cumulative precipitation recorded each hour. To account for periods of intermittent precipitation when branches would remain wet, the hours before and after the hour when precipitation was recorded were considered part of a continuous event.

$\mathrm{b}$ Wind direction was recorded by an observer once each hour. Wind measured at Hillsboro was based on hourly precipitation data from Portland International. 
that ascospores can be transported long distances $(>10 \mathrm{~km}$ on air currents during very light rain) in spite of being discharged from very low heights (i.e., from pseudothecia in leaves on the orchard floor) (4). Thus, with regard to maximum distance of dispersal, ascospores of $A$. anomala may have a similar potential for movement. Moreover, with respect to dispersal distance, ascospores of A. anomala may have a relative advantage over those of $V$. inaequalis, because they are released from an elevated source in a tree canopy devoid of leaves. Ascospores of A. anomala can survive up to 7 days at high relative humidity (J. N. Pinkerton, unpublished data) and are released principally during major rain events which, with corresponding cloud cover, lessens the likelihood of spore mortality from UV exposure (3).

On a regional basis, a chronology of the eastern filbert epidemic in the Pacific Northwest based on survey data $(9,21)$ shows that the disease was introduced at the northern limit of the area of commercial hazelnut production within Washington and Oregon, and that it has spread slowly southward during the past 30 years. More local observations, however, have suggested that the spread of eastern filbert blight is highly directional, south to north (12, 21 ), which was confirmed in the two experiments presented in this study in which young hazelnut trees were placed both to the north and to the south of a diseased orchard and in which directional disease increase was analyzed in a commercial orchard. Thus, as speculated previously (12), weather patterns in the Pacific Northwest, and not the ascospore biology of $A$. anomala, apparently account for the relatively slow southward movement of the disease through the region. Ascospores of A. anomala are discharged only during extended periods of rain, with $99.9 \%$ of ascospores captured during rain events that have durations of $10 \mathrm{~h}$ or more (19). An examination of regional weather data for Oregon's Willamette Valley from 1972 to 1995 showed that wind from the north is rare during rain events $10 \mathrm{~h}$ or more in duration (Table 1). During these events, wind from the north was recorded in $<6 \%$ of the hours, with the majority of cases only $1 \mathrm{~h}$ in duration. Only seven events in 22 years were recorded with wind that was from the north for 4 or more consecutive hours during a major rain event. Regional surveys also have revealed that the spatial pattern of infected orchards in the northern Willamette Valley can be discontinuous, as documented by a small number of isolated diseased orchards found scattered through northern Marion County in the mid-1990s (J. N. Pinkerton, unpublished data). These isolated diseased orchards are south of areas where orchards are generally diseased; therefore, the analysis of weather patterns and the results of this study suggest that these diseased orchards represent potentially important inoculum sources for the rapid spread of eastern filbert back northward on the prevailing winds.

Hazelnut cultivars vary in susceptibility to infection by $A$. anisograma and, consequently, affect rates of disease progress (18). In a survey of hazelnut orchards in Oregon, highly susceptible pollenizers such as Daviana and DuChilly were commonly observed to be the first trees infected within an orchard, serving as foci for further spread within the orchard and local vicinity (21). In the mini-orchard study, disease spread was most rapid and disease more severe in the highly susceptible cv. Ennis. On a relative scale, this faster spread of disease in Ennis mini-orchards was due to a higher number of cankers, a faster rate of canker expansion, and a greater number of ascospores produced in stromata (20). These data are in agreement with observations made in commercial Ennis orchards, which remain productive no more than 5 to 8 years after the first infection, even with the most diligent disease management. Compared with Ennis, numbers of infections and rates of disease increase were substantially lower in mini-orchards of Barcelona and Casina. Unlike Ennis, Barcelona orchards can be kept productive by implementing sanitation, pollenizer replacement, and fungicide applications (13). In the mini-orchard experiment, the close proximity and the strength of the inoculum source used in this study resulted in a higher incidence of infec- tions in Barcelona trees than is usually observed initially in commercial orchards. The rate of disease increase and amount of disease was less in Barcelona mini-orchards planted with Hall's Giant pollenizers compared with those planted with Daviana, suggesting that replacement of highly susceptible pollenizers with moderately resistant pollenizers (16) is a viable management option in areas with low inoculum pressure (i.e., areas in the mid and southern Willamette Valley).

The geographic distribution of eastern filbert blight is currently confined to North America, a region that accounts for less than $5 \%$ of the world hazelnut production. If $A$. anomala were to be introduced into other major hazelnut production areas (e.g., Turkey, Italy, Spain, or France), the epidemic may be dissimilar to that observed in the Pacific Northwest. Weather patterns combined with a disease introduction at the northernmost limit of the production area appear to have reduced the potential for ascospores to disperse rapidly throughout the region. Moreover, in most years, the prolonged rainy season, normally commencing in October, results in release of greater than $90 \%$ of the ascospores before hazelnut becomes susceptible to infection at budbreak in March (20). In other regions of the world, relative inoculum densities of $A$. anomala may be higher during the spring period when the trees are susceptible to infection, and movement of released ascospores on air currents may be less directional than occurs in the Pacific Northwest.

\section{ACKNOWLEDGMENTS}

Research was supported in part by the USDA-ARS and Oregon Agricultural Experiment Station Specific Cooperative Agreement 58-5358-190 and the Oregon Hazelnut Commission.

\section{LITERATURE CITED}

1. Aylor, D. E. 1986. A framework for examining inter-regional aerial transport of fungal spores. Agric. For. Meteorol. 38:263-288.

2. Aylor, D. E. 1995. Vertical variation of aerial concentration of Venturia inaequalis ascospores in an apple orchard. Phytopathology 85:175-181.

3. Aylor, D. E. 1998. The aerobiology of apple scab. Plant Dis. 82:838-849.

4. Aylor, D. E., and Sutton, T. S. 1992. Release of Venturia inaequalis during unsteady rain: Relationship to spore transport and deposition. Phytopathology 82:532-540.

5. Davidson, A. D., and Davidson, R. M., Jr. 1973. Apioporthe and Monchaetia canker reported in western Washington. Plant Dis. Rep. 57:522523.

6. Davis, J. M., and Main, C. E. 1986. Applying atmospheric trajectory analysis to problems in epidemiology. Plant Dis. 70:490-497.

7. Fitt, B. D. L., Gregory, P. H., Todd, A. D., McCartney, H. A., and Macdonald, O. C. 1987. Spore dispersal and plant disease gradients: A comparison between two empirical models. J. Phytopathol. 118:227-242.

8. Gottwald, T. R., and Cameron, H. R. 1979. Morphology and life history of Anisogramma anomala. Mycologia 71:1107-1126.

9. Gottwald, T. R., and Cameron, H. R. 1980. Disease increase and the dynamics of spread of canker caused by Anisogramma anomala in European filbert in the Pacific Northwest. Phytopathology 70:10871092.

10. Gottwald, T. R., and Cameron, H. R. 1980. Infection site, infection period, and latent period of canker caused by Anisogramma anomala in European filbert. Phytopathology 70:1083-1087.

11. Gregory, P. H. 1973. Interpreting plant disease dispersal gradients. Annu. Rev. Phytopathol. 6:189-212.

12. Johnson, K. B., Mehlenbacher, S. A., Stone, J. K., Pscheidt, J. W., and Pinkerton, J. N. 1996. Eastern filbert blight of European hazelnut: It's becoming a manageable disease. Plant Dis. 80:1308-1316.

13. Johnson, K. B., Pinkerton, J. N., Gaudreault, S. M., and Stone, J. K. 1994. Infection of European Hazelnut by Anisogramma anomala: Site of infection and effect of host development stage. Phytopathology 85:14651470.

14. Madden, L. V. 1992. Rainfall and the dispersal of fungal spores. Adv. Plant Pathol. 8:39-79.

15. May, K. R., and Harper, G. L. 1957. The efficiency of various liquid impinger samplers in bacterial aerosols. Br. J. Ind. Med. 14:287-297.

16. Mehlenbacher, S. A., and Thompson, M. M. 1991. Four hazelnut pollenizers resistant to eastern filbert blight. HortScience 26:442-443. 
17. Pedgley, D. E. 1985. Concepts in atmospheric science as they relate to the movement of biotic agents. Pages 175-178 in: The Movement and Dispersal of Agriculturally Important Biotic Agents. D. R. Mackenzie, C. S. Barfield, G. G. Kennedy, R. D. Berger, and D. J. Taranto, eds. Claitor's Publishing Division, Baton Rouge, LA.

18. Pinkerton, J. N., Johnson, K. B., and Mehlenbacher, S. A. 1993. Susceptibility of European hazelnut clones to eastern filbert blight. Plant Dis. 77:261-266.

19. Pinkerton, J. N., Johnson, K. B., Stone, J. K., and Ivors, K. L. 1998. Factors affecting the release of ascospores of Anisogramma anomala. Phytopathology 88:122-128.

20. Pinkerton, J. N., Johnson, K. B., Stone, J. K., and Ivors, K. L. 1998. Maturation and seasonal discharge pattern of ascospores of Anisogramma anomala. Phytopathology 88:1165-1173.

21. Pinkerton, J. N., Johnson, K. B., Theiling, K. M., and Griesbach, J. 1992. Distribution and characteristics of the eastern filbert blight epidemic in western Oregon. Plant Dis. 76:1179-1182.

22. Pinkerton, J. N., Stone, J. K., Nelson, S. J., and Johnson, K. B. 1995. Infection of European hazelnut by Anisogramma anomala: Ascospore adhesion, mode of penetration of immature shoots, and host response. Phytopathology 85:1260-1268.

23. Roelfs, A. P. 1985. Epidemiology in North America. Pages 403-434 in: The Cereal Rusts, Vol. II. W. R. Bushnell and A. P. Rolfs, eds. Academic Press, New York.

24. Stedman, O. J. 1980. Splash droplet and spore dispersal studies in field beans (Vicia faba L.). Agric. Meteorol. 21:111-117.

25. Stone, J. K., Johnson, K. B., Pinkerton, J. N., and Pscheidt, J. W. 1992. Natural infection period and susceptibility of vegetative seedlings of European hazelnut to Anisogramma anomala. Plant Dis. 76:348-352.

26. Stone, J. K., Pinkerton, J. N., and Johnson, K. B. 1994. Axenic culture of Anisogramma anomala: Evidence for self-inhibition of ascospore germination and colony growth. Mycologia 86:674-683. 